\title{
Students' Competence in the TOEFL Structure and Written Expression
}

\author{
Nuur Insan Tangkelangi \\ nourin1204@gmail.com \\ Faculty of Teacher Training and Education, Universitas Cokroaminoto Palopo, \\ Palopo, Indonesia
}

Received: 25 March 2020 Accepted: 29 May 2020

DOI: $10.24256 /$ ideas.v8i1.1271

\begin{abstract}
This study aims to find out the students' competence in answering questions on TOEFL structure and written expression. It mainly focused on Information and Technology students because the current curriculum in the institution requires them to take TOEFL. Ninety-two students from three different classes participated in this study. Data collection was done by utilizing an adopted test consisting of 40 questions was used. The data shows that the students' competence in the TOEFL structure and written expression is low. It is revealed by observing the mean scores of the students, namely 23.75 (class A), 27.5 (class B), and 42.5 (class C). One of the main reasons to explain this scenario is due to their poor English Grammar. Therefore, the study suggests the students should be guided in learning basic-to-advanced level of English Grammar before introducing them to the TOEFL's structure and written expression.
\end{abstract}

Keywords: structure and written expression, students' competence, TOEFL

\section{Introduction}

Test of English as a Foreign Language or better known as TOEFL is one of the famous English language proficiency tests in Indonesia. Obtaining a minimum score in TOEFL is generally one of the requirements for university students to graduate (Bochari,2019; Hajri \& Wahyuni, 2018; Muhajir \& Gani, 2018; Masruddin, 2018; Tanihardjo, 2016). In postgraduate degree, this requirement is applied for all students of all departments. However, in the undergraduate level, it is compulsory students majoring in English to sit for and pass the test. In that regard, numerous studies on English language students had been conducted, and most of the studies put a great emphasis on the competences, difficulties and problems learning the 
language. Hence, there is a need to investigate Information and Technology (IT) students' competence in TOEFL.

In the institution where this study is carried out, IT students are taught a unit discussing TOEFL to prepare them being ready to take the test someday if they want to pursue their next degree of study or if they apply jobs that ask for a TOEFL score. However, because of the limited time of the students' learning in one semester and the massive number of strategies for each section, this unit merely can focus on one of the three sections tested. This section is structure and written expression because the strategy to answer questions in this section requires the test takers to be knowledgeable with grammatical matters in English. These strategies are different from the strategy to answer questions testing the other two sections-listening and reading.

In Indonesia, where English is regarded as a foreign language, learning English Grammar for TOEFL often poses a great challenge for the students. This scenario happened to IT students because they were required to take some elective subjects or units, such as Intermediate EFL Studies and most of its learning contents are related to the strategies in answering TOEFL. On top of that, the lecturers always find difficulty teaching English language due to students' low proficiency in the language. Thus, it is of utmost importance to study students' competency in answering questions related to structure and written expression section in TOEFL.

\section{Method}

This study employed a quantitative approach with descriptive statistical analysis. This study focuses on investigating IT students' competences in the TOEFL structure and written expression in one of the universities in Palopo. Ninety-two IT students from three different classes participated in this study. The classes are taught by the same teacher. The participants were required to complete the structure and written expression sections comprising of 40 questions based on the TOEFL in 40 minutes. The test was adopted from Philips (2001). Microsoft Excel was used to gather and analyzed the data. It was then presented in the graph form.

\section{Results}

The findings of this research are displayed in the following charts, differentiated based on the classes of the participants. The pseudonym was used for confidential purpose. 


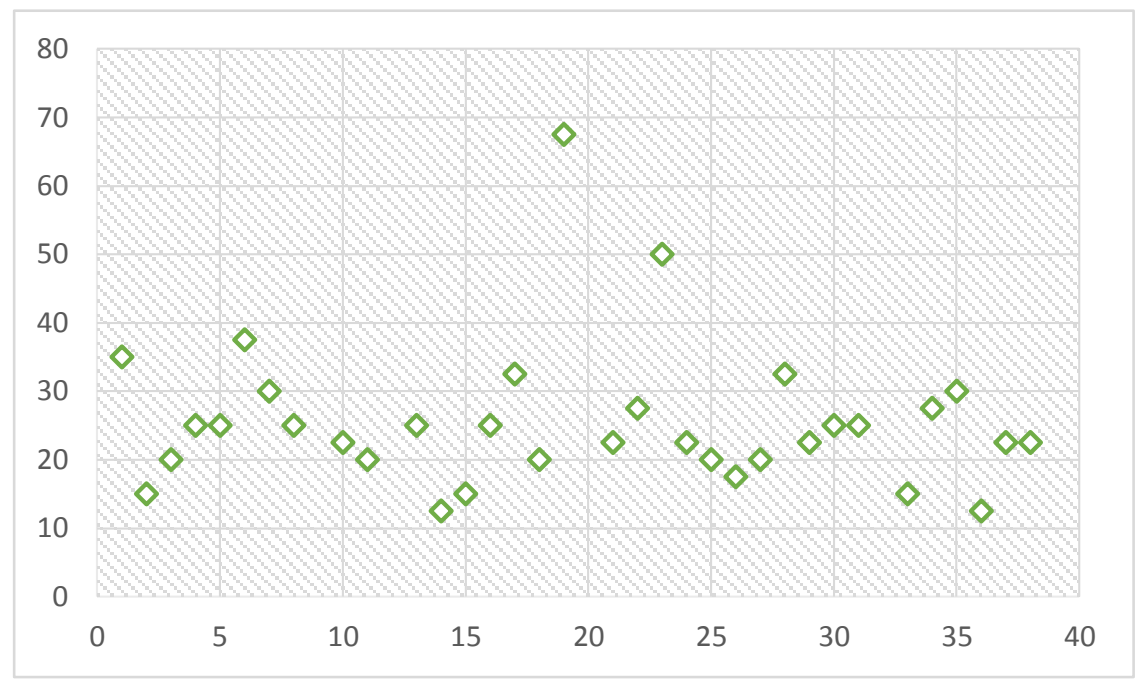

Chart 1. The scores of class $A$ students

Chart 1 above shows the score of class A students on answering 40 questions of TOEFL structure and written expression. The data indicate that the students in class A get a low score in the test given. Most of the students in this class get scores less than 40, one student gets 50, and merely one student can get 67.5. Furthermore, the mean score calculation finds that the mean score of the students in this class is 23.75 out of 100 . The highest score is 67.5 , and the lowest score is 12.5. It implies that the class A students' competence in answering the questions of TOEFL structure and written expression is low. This low competence is due to their less comprehension on advanced-level of English Grammar tested in the TOEFL structure and written expression.

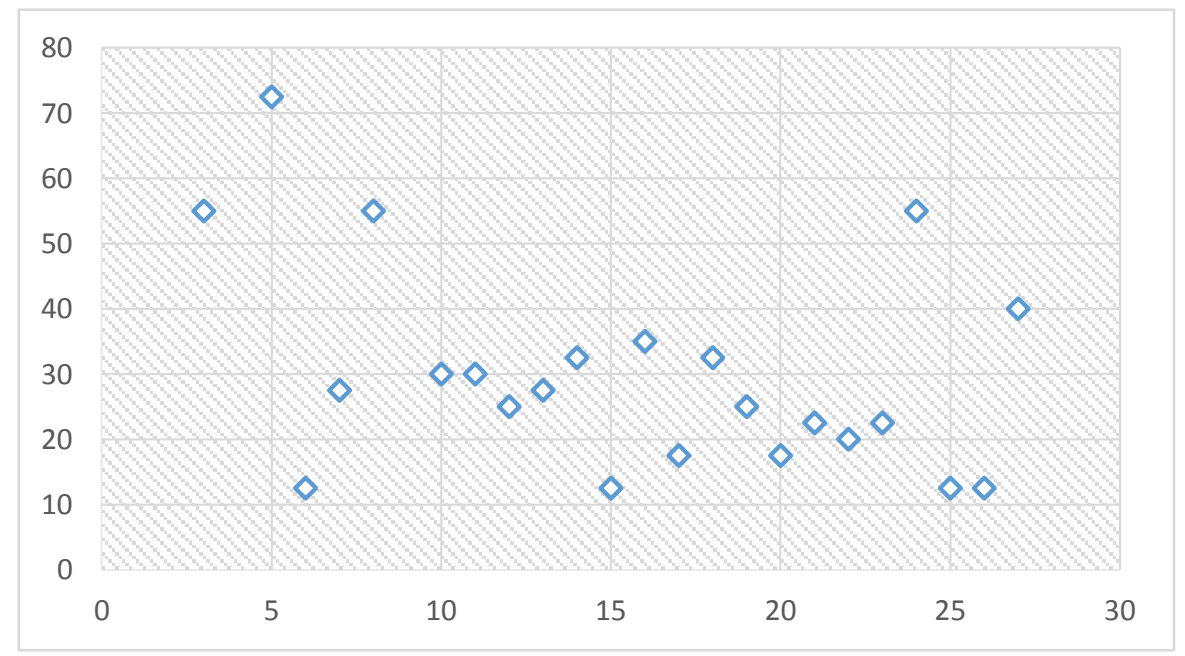

Chart 2. The scores of class B students

The data displayed in the chart above shows the class B students' scores on answering the test given comprising 40 questions of TOEFL structure and written expression. Similar to the data displayed in chart 1, most students get low scores which are under 40 , three students get 55 , and one student gets 72.5 . The mean 
score of this class is 27.5 , and the highest score of the student in this class B is 72.5 . The lowest score got by the student in class B is 12.5. It is an indicator of the low competence of the class B students in answering TOEFL structure and written expression questions. It is due to the lack of comprehension on the grammar rules tested in TOEFL section 2 (structure and written expression) that require an understanding of advanced-level grammar materials.

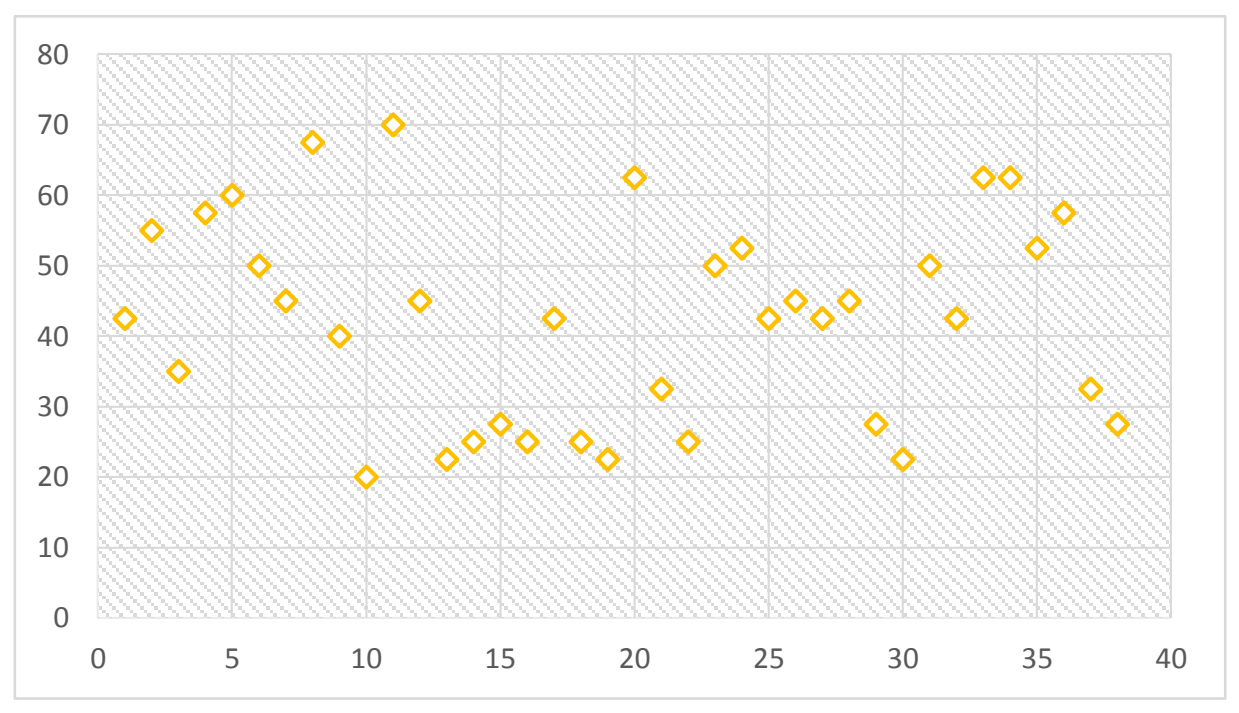

Chart 3. The scores of class $C$ students

The data displayed in chart 3 above show that the class $C$ students' scores are lying from 20 to 70 . The result of mean score calculation shows that the mean score of class $C$ students is 42.5 . This score is still under half of the total score, 50 . The number of students who can get 50 and above is significantly lower than the number of students whose scores under 50. It means that most of the students cannot answer half of the total number of the questions correctly. Similar with the results of class $A$ and $B$ students, the data in the chart above shows that the class $C$ students also have lack comprehension on how to answer the TOEFL structure and written expression section due to the low understanding on grammar materials tested in this section. 


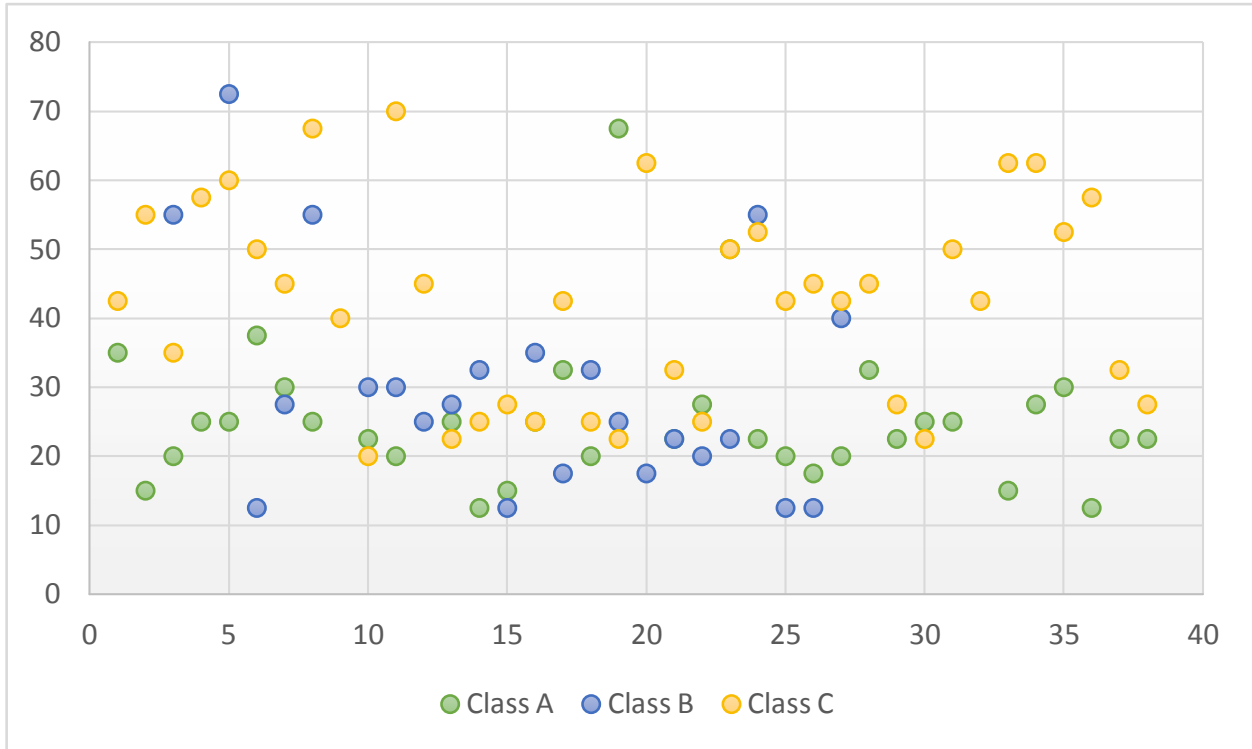

Chart 4. The score of class $A, B$, and $C$ students

The chart above shows the comparison of the students' score among three different classes. It is shown that the scores under 40 are mostly gotten by students of class A and B. Meanwhile, class $C$ students acquire the scores above 40 . Less than ten students from class $\mathrm{A}$ and $\mathrm{B}$ get 40 and above. It indicates that the class $\mathrm{C}$ students' competence in TOEFL structure and written section outstands class A and B students. This situation is also clearly seen at the mean scores of the three classes. The mean score of class $C$ students (42.5) outnumbers the mean score of class A students (23.75) and class B students (27.5). It means the class B students' competence in TOEFL structure and written section is higher than class A, and the class $\mathrm{C}$ students' competence in TOEFL structure and written part is higher than class B.

Pondering the reason why these classes have different results, prior knowledge of the students is the possible answer. This factor is considered as the most reliable one because the test is given before the unit discussing TOEFL was started. Therefore, the prior knowledge (input) of the students takes an important place in these results.

\section{Discussion}

Based on the data displayed in the result section above, it is identified that the students' competence in answering the questions in the TOEFL grammar section is low. Although class $C$ gets higher scores compared to two other classes, the scores are still low. Merely one out of thirty-eight students can get seventy, and only five students can get sixty and above. The rest of the students can only reach fifty and under fifty. This picture is a clear indication teaching English grammar is absolutely necessary. Since these students come from an EFL setting, they should be exposed to basic Grammar first. Besides, since they learn Grammar for the test, the lecturers need to apply fun and interactive approach that could help these students learn 
Grammar better.

The results of other studies investigating the same issue in different contexts also show a similar picture. Research by Tilana, Yunita, \& Zahrida (2019), reveals that the students' competence in structure and written expression is low. They found that the most confusing topic for the students is redundancy. The confusion was due to ambiguity and the first language interference. $\mathrm{n}$ the end, the authors emphasize that the most influential factor contributing to the students' low competence in the structure and written expression is their poor English Grammar. Interestingly, the students participating in the research were majoring in English. It is a clear indicator that even English students have the low ability to answer structure and written expression section.

Furthermore, there was a similar research conducted by Hajri and Wahyuni (2018). The study reveals that eleven out of eighteen topics assessed in the grammar section on TOEFL are difficult for the students. The most difficult ones are "negation format in a sentence, reduced adjective in passive, and parallel in noun phrase" (Hajri \& Wahyuni, 2018, p. 100). These grammar topics are challenging for those who are not majoring English and who are not using English as their mother tongue, first language, or second language. However, the results uncovered by Hajri and Wahyuni shows that even the English students who have already taken units on Grammar 1, 2, 3, 4, and Functional Grammar perceive these topics difficult. It implies that advanced understanding of English Grammar is required.

The two studies discussed above show that matters tested in structure and written expression is in the advanced level, which requires the test takers to have an advanced understanding of English Grammar. The two previous studies above indicate that even students were majoring English face difficulties in answering the questions in structure and written expression on TOEFL. Compared to the students participating in the present study, it can be projected that they need to intensively learn more English Grammar from the basic to the advanced level before discussing questions on structure and written expression. Moreover, it is also suggested to provide various English language programs that enable the students to learn English beside of the English units. Having TOEFL seminars discussing the latest trend of the test is also recommended.

The findings displayed in the previous section show that the students' competence in answering questions in structure and written expression TOEFL is low. This condition might be caused by the same problem faced by the students participating in the previous studies discussed above, namely lack of comprehension on grammar rules. Therefore, it is recommended to guide the students to master basic-to-advanced level of English Grammar before guiding them to answer the questions tested in structure and written expression in TOEFL. If the students are forced to learn about grammatical matters tested in TOEFL, not 
only the students face difficulties to learn the materials, but also the teachers will face difficulties to guide the students to learn.

\section{Conclusion}

Based on the findings in this research, it is concluded that the students' competence in answering questions in TOEFL grammar section is low. The factor causes this condition might be the same with the causal factor found by other studies, namely the students' lack understanding of English Grammar. Therefore, it is suggested to guide the students to learn the basic-to-advanced level of English Grammar before teaching them how to answer the questions on TOEFL structure and written expression correctly. Further studies are invited to be carried out to find out the English grammar materials which are needed by the students to be able to deal with items on TOEFL grammar section. Lastly, the result of this study is expected to be a meaningful insight for the next unit designers or the unit lecturers in designing and in delivering the unit teaching TOEFL at the next semester.

\section{Acknowledgement}

I want to express my gratitude to the Almighty God, who has given me blessing and guidance in finishing this study. Moreover, I would also like to express my big thanks to my relatives and friends for their meaningful support. Finally, my special thanks go to those who voluntarily participated in this study. This study would not have been completed without these parties. Thank you very much.

\section{References}

Bochari, S., Basri, H., \& Arid, M. (2019). The Student's Error in Forming Nominal Clause in Complex Sentence. IDEAS: Journal on English Language Teaching and Learning, Linguistics and Literature, 7(2). doi:https://doi.org/10.24256/ideas.v7i2.1085

Hajri, T., \& Wahyuni, D. (2018). An analysis of difficulties in answering structure and written expression of TOEFL made by English students of Universitas Negeri Padang. 7(1), 13.

Masruddin, M., \& Kurnia, K. (2018). Improving Students Writing Skill by Using Picture at The Twelfth Year Students of Sma Pesantren Modern Datok Sulaiman Putra Palopo. IDEAS: Journal on English Language Teaching and Learning, Linguistics and Literature, 3(2). doi:https://doi.org/10.24256/ideas.v3i2.152

Muhajir \& Gani, S. A. (2018). Students' difficulties in mastering structure and written expression of paper-based TOEFL. 3(2), 136-143.

Phillips, D. (2001). Longman complete course for the TOEFL test. New York: Longman.

Swales, J. M., \& Feak, C. B. (2004). Academic writing for graduate students: Essential tasks and skills (2nd ed.). Michigan: The University of Michigan 
Nuur Insan Tangkelangi

Students' Competence in the Structure and Written Expression Section of TOEFL

Press.

Tanihardjo, J. (2016). The analysis of students' English competence in the grammar section in the paper-based TOEFL: A case study at English Department in Bunda Mulia University. 6(1), 19-30.

Tilana, P. E., Yunita, W., \& Zahrida. (2019). Students' English structure and written competence. Journal of English Education and Teaching, 3(2), 180-194. https://doi.org/10.33369/jeet.3.2.180-194 